\title{
Ultrastructure of the silk glands in three adult females of sphecid wasps of the genus Microstigmus (Hymenoptera: Pemphredoninae)
}

\author{
Ultraestructura de las glándulas de seda en hembras adultas de tres especies de avispas del \\ género Microstigmus (Hymenoptera: Sphecidae: Pemphredoninae)
}

JOSÉ EDUARDO SERRÃO

Departamento de Biologia Geral, Universidade Federal de Viçosa, 36570-000 Viçosa, MG, Brasil; e-mail: jeserrao@ufv.br

\begin{abstract}
The ultrastructure of silk glands in adult females of sphecid wasps is described. Individual glands are scattered in the more posterior portion of the metasoma being each gland formed by an enlarged secretory unity with one conducting canal. Each secretory unit is a gland cell containing a large lumen and numerous secretory granules, which are delimited by membrane and filled with middle electron dense content of homogeneous aspect, which are exocytosed into the extra cellular lumen. Cell cytoplasm is filled with rough endoplasmic reticulum, polyribosomes and Golgi apparatuses profiles. The basal plasma membrane has many short infoldings and is lined by a thin basement membrane. The apical membrane is invaginated to form the boundary of the lumen, containing scattered short microvilli. The cells are mononucleated and the nucleus is pleomorphic containing disperse chromatin. The extracellular lumen is separated of the receiving canal by a convoluted sponge-like wall forming many villi, which in their tip are lined by a thin single layered cuticle. In the basal region of the villi a cuticular covering is lacking. In the conducting canal secretion acquire two different electron densities. A thin cuticle lines the lumen of conducting canal and the cell cytoplasm is scarce and the organelles are represented for few rough endoplasmic reticulum and polyribosomes. These results are discussed in relation to function and origin of silk gland in adult Sphecidae.
\end{abstract}

Key words: Hymenoptera, Microstigmus, silk glands, Sphecidae, ultrastructure.

\section{RESUMEN}

Se describe la ultraestructura de las glándulas de la seda en tres hembras adultas de avispas Sphecidae del género Microstigmus. Las glándulas individualmente se dispersan en la porción más posterior del metasoma, y cada una de ellas está formada por una unidad secretora grande y un canal que conduce la secreción. Cada célula de la unidad secretora contiene un gran lumen y numerosos gránulos secretores, los que están delimitados por una membrana y repletos de un contenido denso a los electrones de aspecto homogéneo, el que es eliminado hacia el lumen. El citoplasma de la célula está repleto de perfiles del retículo endoplasmático granular, de polirribosomas y de aparatos de Golgi. La membrana plasmática basal presenta muchos repliegues cortos hacia el interior y está revestida por una membrana basal fina. La membrana plasmática apical está invaginada para formar el límite del lumen extracelular, lleva microvellosidades cortas y dispersas. Las células son mononucleadas y el núcleo es de forma variada y contiene cromatina dispersa. El lumen está separado del canal de recepción por una pared replegada semejante a una esponja, con muchas vellosidades, las que en su extremidad están delimitadas por una cutícula fina. En la región basal, las vellosidades carecen de cubierta cuticular. El canal que conduce la secreción adquiere dos densidades de electrones diferentes. Una cutícula fina reviste el lumen del canal que conduce la secreción, siendo escaso el citoplasma de la célula y conteniendo poco retículo endoplasmático granular y polirribosomas. Estos resultados se discuten en relación a la función y al origen de la glándula de seda en los adultos de Sphecidae.

Palabras clave: Hymenoptera, Microstigmus, glándulas de seda, Sphecidae, ultrastructura.

\section{INTRODUCTION}

Production of silk in insects is widely distributed among holometabolous groups in larval forms, e.g., some Lepidoptera, Hymenoptera, Coleoptera, Neuroptera and Diptera (Michener 1974, Kentchington 1983, Sehnal \& Akai 1990). On the other hand, 
production of silk in adult species is restrict to a few species of Hymenoptera, Psocoptera, Hemiptera, Diptera and Embioptera (Weber 1930, Sehnal \& Akai 1990, Nagashima et al. 1991, Melo 1997, Serrão \& Campos 2000, Young \& Merrit 2003).

Among Hymenoptera, silk production in adult forms has been reported for Chalcidoidea (Delanoue \& Arambour 1965, Wooley \& Vet 1981), Vespidae (Singer et al. 1992) and Sphecidae (Melo 1997).

In sphecid wasps the silk produced by female member of Pemphredoninae is used in nest construction, being the silk glands situated in the abdomen (metasoma), opening to the exterior by means of bristles acting like spinnerets in the formation of silk thread (Melo 1997, Serrão \& Campos 2000). The silk glands cells are scattered in the more posterior portion of the metasoma, being formed by enlarged secretory units (gland cell) each with one conducting canal (Serrão \& Campos 2000). An ultrastructural description of the silk gland apparatus, based on transmission electron microscopy is given in this paper to address the general ultrastructure of the silk glands in adult sphecid wasps.

\section{MATERIAL AND METHODS}

The material used in this study consisted of adult females of Microstigmus nigrophthalmus, Microstigmus brasiliensis and Microstigmus arlei captured in Viçosa, MG, Brazil. The abdomen (metasoma) after having been cut out of the body of the insects were carefully cut in the lateral middle-line and transferred to $2.5 \%$ glutaraldehyde in sodium cacodylate buffer $0.1 \mathrm{M}$ for $4 \mathrm{~h}$ at room temperature. After washing in the same buffer, pieces were post-fixed in $1 \%$ osmium tetroxide solution for $2 \mathrm{~h}$, followed by stain en bloc overnight at $4{ }^{\circ} \mathrm{C}$ with $1 \%$ uranyl acetate in ethanol $10^{\circ}$. Subsequently the abdomen were dehydrated in a graded acetone series and embedded in Epon-Araltide.

Semi-thin sections were stained with toluidine blue borate and analyzed by light microscopy. Ultrathin sections were stained with uranyl acetate and lead citrate and examined in a Zeiss EM 109 transmission electron microscope (TEM).

\section{RESULTS}

Individual glands are scattered in the more posterior portion of the metasoma. Each gland is formed by an enlarged secretory unity with one conducting canal, which open to exterior by spinnerets such as observed in other Pemphredoninae by Serrão \& Campos (2000).

Each secretory unit is a gland cell containing a large extra cellular lumen and numerous secretory granules with diameter up to $2.0 \mu \mathrm{m}$. (Fig. 1A). The secretory granules are delimited by membrane and filled with middle electron dense content of homogeneous aspect, which are exocytosed into the extra cellular lumen (Fig. 1B, $1 \mathrm{~F}$, and $2 \mathrm{~A}$ ). In addition to secretory granules the cell cytoplasm is filled with rough endoplasmic reticulum, polyribosomes and Golgi apparatuses profiles (Fig. 1C and 1D). The basal plasma membrane has many short infoldings and is lined by a thin basement membrane (Fig. 1E). The apical membrane is invaginated to form the boundary of the extra cellular lumen, containing scattered short microvilli with constant diameter of $0.13 \mu \mathrm{m}$ (Fig. 1F). The cells are mononucleated and the nucleus is pleomorphic containing disperse chromatin (Fig. 2A).

The extra cellular lumen is filled with secretion with similar electron density of those found into cytoplasm of secretory vesicles. The extra cellular lumen is separated of the receiving canal by a thin (0.2-0.6 $\mu \mathrm{m})$ convoluted sponge-like wall (Fig. 1B, $2 \mathrm{~B}$, and $2 \mathrm{C}$ ). The convolution of the receiving canal wall form many villi, which in their tip are lined by a thin single layered cuticle $(0.1 \mu \mathrm{m})$ and an epicuticle ( $25 \mathrm{~nm}$ ) (Fig. 1B, 2B, and 2C). In the basal region of the villi (crypt) a cuticular covering is lacking (Fig. 1B and 2C).

From the lumen of receiving canal, secretion has access to the lumen of conducting canal, where secretion acquire two aspects: a spherical electron transparent content and a crescent-shape more electron dense content (Fig. 2D and 2E). A thin cuticle $(0.1 \mu \mathrm{m})$ lines the lumen of conducting canal. The epithelial cell has scarce cytoplasm containing rough endoplasmic reticulum profiles and few polyribosomes (Fig. 2D and 2E), although the nucleus is well developed with some disperse chromatin (Fig. 2D). The basal plasma membrane is smooth and it is agreed upon a thin and homogeneous basement membrane, while the cell apex is also smooth (Fig. 2E). 


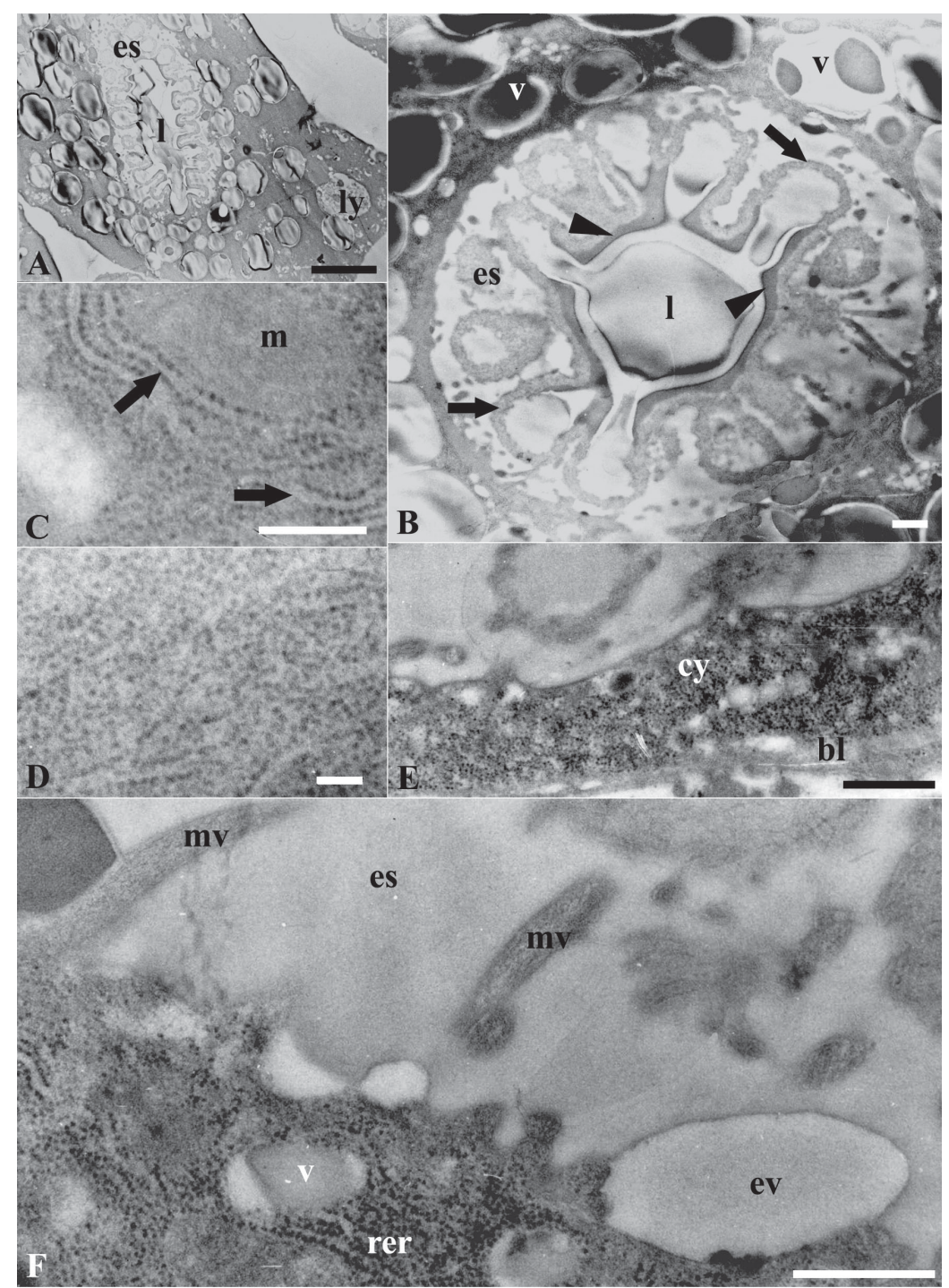

Fig. 1: Silk gland of Microstigmus brasiliensis. (A) Silk gland cell with large vesicles (v) in the cytoplasm, an enlarged extracellular lumen (es), and the lumen (l) of receiving canal; (ly) lysosome; bar $=5 \mu \mathrm{m}$. (B) Extracellular lumen (es) showing the receiving canal lumen (l) lined by a convoluted wall (arrows) which present cuticle in the tips (arrowheads); $v$-secretory vesicles; bar = $1 \mu \mathrm{m}$. (C) Rough endoplasmic reticulum (arrows) in the cytoplasm of gland cell; (m) mitochondria; bar $=0.5 \mu \mathrm{m}$. (D) Cytoplasm portion of gland cell with many polyribosomes; bar $=0.1 \mu \mathrm{m}$. (E) Basal region of gland cell showing short plasma membrane infolding and a thin basement membrane (bl); (cy) cytoplasm; bar $=1 \mu \mathrm{m}$. (F) Apical region of gland cell showing vesicles (v) in the cytoplasm and being exocytosed (ev) to the extracellular lumen (es), which is filled with content presenting similar electron density to those in vesicles. Notice a few short microvilli (mv) and rough endoplasmic reticulum profiles (rer); bar $=0.5 \mu \mathrm{m}$.

Glándula de seda del Microstigmus brasiliensis. (A) Célula de la glándula de seda que demuestra las grandes vesículas (v) en el citoplasma, un lumen extracelular agrandado (es) y el lumen (l) del canal receptor; (ly) lisosoma; barra $=5 \mu \mathrm{m}$. (B) El lumen extracelular (es) que muestra el lumen del canal de recepción (1) delimitado por una pared replegada (flechas) que tiene cutícula en las extremidades (puntas de flecha); (v) vesículas secretoras; barra $=1 \mu \mathrm{m}$. (C) Retículo endoplasmático granular (flechas) en el citoplasma de la célula de la glándula; (m) mitocondria; barra =0,5 $\mu \mathrm{m}$. (D) Porción del citoplasma de la célula de la glándula con muchos polirribosomas; barra $=0,1 \mu \mathrm{m}$. (E) Región basal de la célula de la glándula que muestra la membrana plasmática con un par de cortos repliegues en el interior y una fina membrana basal (bl); (cy) citoplasma; barra $=1 \mu \mathrm{m}$. (F) La región apical de la célula de la glándula que muestra las vesículas (v) en el citoplasma y vesículas eliminando su contenido (ev) al lumen extracelular (es), que se llena del contenido que tiene densidad de electrones similar al de las vesículas. Note algunas microvellosidades cortas (mv) y retículo endoplasmático granular (rer); barra $=0,5 \mu \mathrm{m}$. 


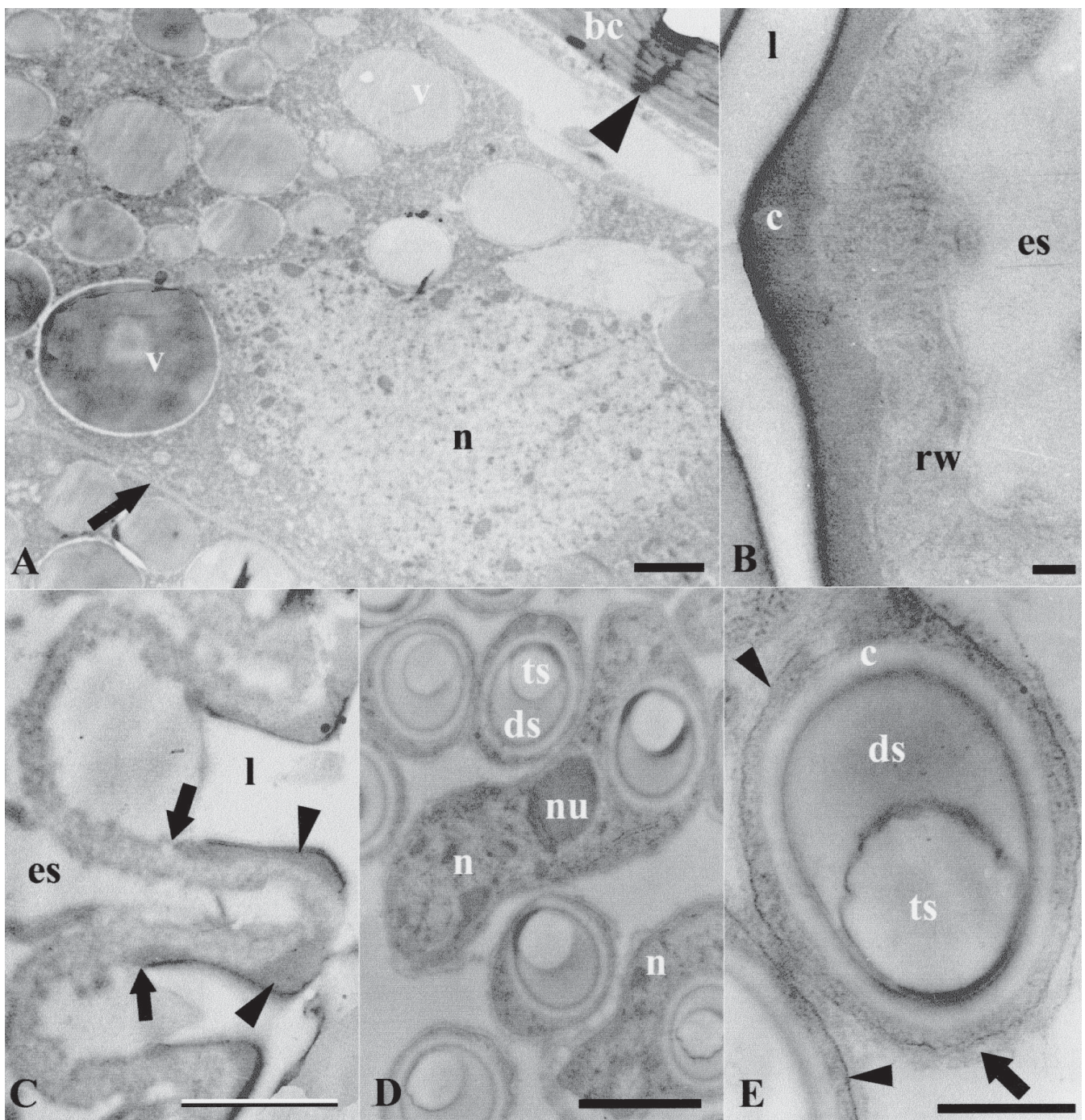

Fig. 2: Silk gland of Microstigmus brasiliensis. (A) Gland cell showing nucleus (n) rich in descondensed chromatin and secretory vesicles (v) with different sizes and electron densities in the cytoplasm. Notice the body cuticle (bc) containing the origin of the spinneret (arrowhead); (arrow) basement membrane; bar $=2 \mu \mathrm{m}$. (B) Extracellular lumen (es) and receiving canal lumen (l) separated by a sponge-like wall (rw) lined by cuticle (c) forming the tip of villus; bar $=0.1 \mu \mathrm{m}$. (C) Receiving canal wall showing a villus with thick cuticle in the tip (arrowheads), which is lacking in the basal crypt. Notice the point of cuticle disappearing (arrows); (es) extracellular lumen; (1) receiving canal lumen; $b a r=1 \mu \mathrm{m}$. (D) Conduction canals showing lumen with electron transparent (ts) and electron dense (ds) secretions. Notice the nucleus (n) of conducting canal cell with well developed nucleolus (nu); bar $=1 \mu \mathrm{m}$. (E) Detailed view of conducting canal showing a thin layer of cytoplasm and the lumen, lined by cuticle (c), filled with electron transparent (ts) and electron dense (ds) contents; (arrow) basement membrane; (arrowheads) plasma membrane; bar $=0.5 \mu \mathrm{m}$.

Glándula de seda del Microstigmus brasiliensis. (A) Célula de la glándula que muestra el núcleo (n) rico en cromatina dispersa y las vesículas secretoras (v) con diversos tamaños y densidades de electrones en el citoplasma. Note la cutícula del cuerpo (bc) conteniendo el origen de una hilandera (punta de flecha); (flecha) membrana basal; barra $=2 \mu \mathrm{m}$. (B) El lumen extracelular (es) y el lumen del canal de recepción (1) separados por una pared como la esponja (rw) revestida por la cutícula (c) formando la extremidad de las vellosidades; barra $=0,1 \mu \mathrm{m}$. (C) En la pared del canal de recepción se muestra una vellosidad con cutícula gruesa en su extremidad (puntas de flecha), pero ausente en la porción basal. Note el punto de la cutícula que desaparece (flechas); (es) lumen extracelular; (1) lumen del canal recibe; barra = $1 \mu \mathrm{m}$. (D) Canales conductores que muestran el lumen con secreciones electrón transparente (ts) y densas (ds). Note el núcleo (n) de la célula del canal que conduce con el nucleolo bien desarrollado (nu); barra $=1 \mu \mathrm{m}$. (E) Vista detallada del canal conductor mostrando una capa delgada del citoplasma y del lumen, revestido por cutícula (c) y relleno del contenido electrón transparente (ts) y electrón denso (ds); (flecha) membrana basal; (puntas de flecha) membrana plasmática; barra $=0,5 \mu \mathrm{m}$. 


\section{DISCUSSION}

The gland cells in Microstigmus spp. are mononucleated, contrasting with multinuclear cells found in silk gland cells of Embioptera by Alberti \& Storch (1976) and Nagashima et al. (1991). On the other hand, mononucleated gland cells are found in silk glands of Hilarini flies (Young \& Merrit 2003). Thus previous finding of Serrão \& Campos (2000) that silk gland cells in Microstigmus are multinucleated was a misinterpretation, perhaps due to artifacts in Feulgen reaction.

Ultrastructural features herein presented clearly showed that the gland cells are of type III according to classification of Noirot \& Quennnedey (1991) for epidermal glands, corroborating suggestions of Melo (1997) and Serrão \& Campos (2000) based upon anatomical and histological studies, respectively. This gland cell class generally is composed by three cell types: gland (terminal), intercalary and canal cells (Noirot \& Quennnedey 1991, Kölsch 2000), but I found only the gland and canal cells, which was also found in hypopharyngeal and epidermal glands in Hymenoptera (Cruz-Landim 1967, CruzLandim \& Saenz 1972, Gama \& Cruz-Landim 1982, Cruz-Landim \& Costa 1997), in spinning organ of Embioptera (Nagashima et al. 1991), in silk-producing basitarsus in Hilarini (Young $\&$ Merrit 2003) and in epidermal glands of Isoptera (Sobotnik et al. 2003).

Typically terminal and intercalary cells possesses numerous microvilli towards the extracellular space, which leads to an increase in the surface area of the cell membrane for transport process. However intercalary cell and microvilli in terminal cell are lacking in the silk glands of Microstigmus. Since the secretory vesicles are very large their content can be exocytosed in great amount even without enlargement of surface area by microvilli. In addition the receiving canal wall has extensive folds forming large villi, being this contact area sufficiently large to transport of secretion into the receiving lumen. The sponge-like aspect of the receiving canal wall facilitates the transport process for sure. A sponge-like wall in receiving canal was also observed in Hilarempis sp. tarsal silk glands where intercalary cells are lacking (Young \& Merrit 2003). The cuticle in the tip maintains the villi in the receiving canal wall, while in the middle basal portion transport across the wall should be intense because cuticle is lacking. The absence of organelles in this wall suggests that the transport occurs without energy consume.

The concentration of secretion in vesicles is largely accepted to be characteristic of regulated secretion. This type of cell secretion is an expected result, because the silk produced by these gland cells are used in nest construction (Melo 1997). Since construction of new brood cells in the nest occurs before egg laying, the female should be able to this task during eggs maturation and an accumulation of material for silk production can be a strategy for fast brood cell construction.

The secretion into secretory vesicles should be proteinaceous. This assumption is based on circumstantial evidence of the high amount of rough endoplasmic reticulum in gland cell cytoplasm and in previous report that this gland are silk-producing (Melo 1997, Serrão \& Campos 2000).

The major component of commercial silk thread is fibroin, being its major amino acid composition constituted by Gly, Ala and Ser, a similar composition found in silk produced by larval sphecid wasp Psenulus concolor, which has also Pro, Asp and Glu (Sehnal \& Akai 1990, Craig et al. 1999). Although other smaller proteins may be associated, the principal one is sericin (Sehnal \& Akai 1990). Fibroin and sericin are synthesized by different cells in different regions of labial silk glands in larvae (Fukuda 1960, Silva-de-Moraes \& CruzLandim 1979, Sehnal \& Akai 1990, Qader \& Haque 1996). Under TEM, fibroin is seen inside the secretory vesicles forming elementary fibers and as the secretion access the gland lumen the fibers adhere to one another (Akai \& Kataoka 1978) while sericin acquire a flocculent aspect. In Embioptera where sericin and fibroin are synthesized by the same cell it is possible to recognize these proteins in different vesicles and places in the gland lumen as can be analyzed in the micrographs supplied by Nagashima et al. (1991). In the fly Hilarempis the micrographs of silk gland presented by Young \& Merrit (2003) shown many vesicles and lumen contents with fibrous aspect. However, in this study I never found fiber-like material in secretory vesicles or in extracellular lumen of 
gland cell neither in the conducting canal, but the hypothesis that different components can be secreted at different times in the same cell is also possible, because I found often the presence of two types of secretion with different electron densities inside the conducting canal lumen, but they never acquired a fibrous aspect. Therefore I suggest that silk produced by adult sphecid wasp may has a different composition from those found in other insects, which is supported by the hypothesis of Craig et al. (1999) that amino acid composition of silks produced by different insect orders is highly variable showing phylogenetic and diet relationships and perhaps its polymerization start out of the body and not inside vesicles or canal lumen.

Young \& Merrit (2003) hypothesized that all dermal silk glands of insects, and indeed the class III glands could be evolutionarily derived from contact chemoreceptive sensilla that retained the hair shaft to allow silk application with consequent lose of its sensory neural component of course. However, hair-like uniporous contact chemoreceptive sensilla usually have sockets giving them some mobility (Chapman 1998). In this sense, spinnerets in adult sphecid wasps have no socket and can be recognized as body cuticle evagination (Serrão \& Campos 2000), which does not corroborate the previous hypothesis. Thus future studies on this theme, e.g., at level of gene identity, should be made to address this subject matter.

\section{ACKNOWLEDGMENTS}

I thank Dr K. Matsuoka for making available the transmission electron microscope used and to Dr. L.A.O. Campos and Dr. G.A.R. Melo for aid in the collect and identification of the specimens used. This research was supported by Brazilian research agencies National Research Council and Minas Geraes State Research Council.

\section{LITERATURE CITED}

AKAI H \& K KATAOKA (1978) Fine structure of liquid fibroin in the posterior silk gland of Bombyx larvae. Journal of Sericulture Science of Japan 47: 273278
ALBERTI G \& V STORCH (1976) Transmissions-und rasterelektronenmikroskopische Untersuchung der Spinndrüsen von Embien (Embioptera, Insecta). Zoologischer Anzeiger 197: 179-186.

CHAPMAN RF (1998) The insects: structure and function. Fourth edition. Cambridge University Press, Cambridge, United Kingdom. xvii +770 pp.

CRAIG CL, M HSU, D KAPLARI \& NE PIERCE (1999) A comparison of the composition of silk proteins produced in spiders and insects. International Journal of Biological Macromolecules 24: 109-118.

CRUZ-LANDIM C (1967) Estudo comparativo de algumas glândulas de das abelhas (Hym., Apoidea) e respectivas implicações evolutivas. Arquivos de Zoologia 15: $177-290$.

CRUZ-LANDIM C \& MHP SAENZ (1972) Estudo comparativo de algumas glândulas dos Vespoidea (Hymenoptera). Papéis Avulsos de Zoologia 25: 251-263

CRUZ-LANDIM C \& RAC COSTA (1997) Structure and function of the hypopharyngeal glands of Hymenoptera: a comparative approach. Journal of Comparative Biology 3: 151-163.

DELANOUE P \& Y ARAMBOUR (1965) Contribution à l'étude en laboratoire d'Eupeulmus urozomus Dalm. (Hymenoptera, Chalcidoidea, Eupelmidae). Annales de la Societé Entomologique de France (nouvelle série) 1: 817-842.

FUKUDA T (1960) Biochemical studies on the formation of silk protein during the growth of the silkworm larva. Bulletin of the Agricultural Chemical Society of Japan 24: 396-401.

GAMA V \& C CRUZ-LANDIM (1982) Estudo comparativo das glândulas do sistema salivar de formigas (Hymenoptera: Formicidae). Naturalia 7: 145-165.

KENTCHINGTON T (1983) The larval silk gland of Hypera spp. (Coleoptera: Curculionidae). A new example of the cross-b protein conformation in an insect silk. Journal of Insect Physiology 29: 355361.

KÖLSCH G (2000) The ultrastructure of glands and the production and function of the secretion in the adhesive capture apparatus of Stenus species (Coleoptera: Staphylinidae). Canadian Journal of Zoology 78: 465-475.

MELO GAR (1997) Silk glands in adult sphecid wasps (Hymenoptera, Sphecidae, Pemphredoninae). Journal of Hymenoptera Research 6: 01-09.

MICHENER CD (1974) The social behavior of bees: a comparative study. Harvard University Press, Cambridge, Massachusetts, USA. xii $+341 \mathrm{pp}$.

NAGASHIMA T, N NIWA, S OKAJIMA, \& T NONAKA (1991) Ultrastructure of silk gland of webspinner Oligotoma japonica (Insecta Embioptera). Cytologia 56: 679-685.

NOIROT C \& A QUENNEDEY (1991) Glands, gland cells, glandular units: Some comments on terminology and clasification. Annales de la Societe Entomologique de France (nouvelle sèrie) 27: 123-128.

QADER MA \& T HAQUE (1996) Estimation of fibroin protein in posterior silk gland of Bombyx mori feeding mulberry leaves under different cultivation forms. Pakistan Journal of Zoology 28: 09-12.

SEHNAL F \& H AKAI (1990) Insect silk glands their types, development and function and effects of environmental factors and morphogenetic hormones on them. International Journal of Insect Morphology \& Embryology 19: 79-132.

SERRÃO JE \& LAO CAMPOS (2000) Notes on the structure of silk glands in sphecid wasps, Microstigmus and Psenulus (Hymenoptera, 
Sphecidae, Pemphredoninae). Netherlands Journal of Zoology 50: 479-486.

SILVA-DE-MORAES RLM \& C CRUZ-LANDIM (1979) Estudos ultra-estruturais da glândula salivar larval de Melipona quadrifasciata anthidioides Lep. Durante o desenvolvimento larval. Revista Brasileira de Biologia 39: 103-116.

SINGER TL, KE ESPELIE \& DS HIMMELSBACH (1992) Ultrastructural and chemical examination of paper and pedicel from laboratory and field nests of the social wasp Polistes metricus Say. Journal of Chemical Ecology 18: 77-86.

SOBOTNIK J, F WEYDA \& R HANUS (2003) Ultrastructure of epidermal glands in neotenic reproductives of the termite Prorhinotermes simplex (Isoptera: Rhinotermitidae). Arthropod Structure \& Development 32: 201-208.

WEBER H (1930) Biologie der Hemipteren. SpringerVerlag, Berlin, Germany. 166 pp.

WOOLEY JB \& LEM VET (1981) Postovipositional webspinning behavior in a hyperparasite, Signiphora coquiletti Ashmead (Hymenoptera: Signiphoridae). Netherlands Journal of Zoology 31: 627-633.

YOUNG JH \& DJ MERRIT (2003) The ultrastructure and function of the silk-producing basitarsus in the Hilarini (Diptera: Empididae). Arthropod Structure \& Development 32: 157-165. 